\title{
Direct Evidence of Ice Crystallization Inhibition by Dielectric Relaxation of Hydrated Ions
}

\author{
Xiaoyuan Song $(\mathbb{D}$, Lisheng Zhong $* \mathbb{1}$ and Jinghui Gao *(D) \\ State Key Laboratory of Electrical Insulation and Power Equipment, Xi'an Jiaotong University, \\ Xi'an 710049, China; xiaoyuansongxys@stu.xjtu.edu.cn \\ * Correspondence: lszhong@mail.xjtu.edu.cn (L.Z.); gaojinghui@mail.xjtu.edu.cn (J.G.)
}

check for

updates

Citation: Song, X.; Zhong, L.; Gao, J. Direct Evidence of Ice Crystallization Inhibition by Dielectric Relaxation of Hydrated Ions. Materials 2021, 14, 6975. https://doi.org/10.3390/ ma14226975

Academic Editor: Junwei Zha

Received: 30 September 2021 Accepted: 15 November 2021 Published: 18 November 2021

Publisher's Note: MDPI stays neutral with regard to jurisdictional claims in published maps and institutional affiliations.

Copyright: (c) 2021 by the authors. Licensee MDPI, Basel, Switzerland. This article is an open access article distributed under the terms and conditions of the Creative Commons Attribution (CC BY) license (https:// creativecommons.org/licenses/by/ $4.0 /)$.

\begin{abstract}
In this paper, the inhibition effect of an alternative current (AC) electric field on ice crystallization in 0.9 wt \% NaCl aqueous solution was confirmed thermodynamically with characterization. An innovative experimental and analytical method, combining differential scanning calorimeter (DSC) measurement with an externally applied electric field was created by implanting microelectrodes in a sample crucible. It was found that the ice crystallization, including pure ice and salty ice, was obviously inhibited after field cooling with an external AC electric field in a frequency range of $100 \mathrm{k}-10 \mathrm{MHz}$, and the crystallization ratio was related to frequency. Compared with non-field cooling, the crystallization ratio of ice crystals was reduced to less than $20 \%$ when $E=57.8 \mathrm{kV} / \mathrm{m}$ and $f=1 \mathrm{MHz}$. The dielectric spectrum results show that this inhibition effect of an alternating electric field on ice crystal growth is closely related to the dielectric relaxation process of hydrated ions.
\end{abstract}

Keywords: ice crystals; microelectrodes; electric field; dielectric relaxation; hydrated ions

\section{Introduction}

Water-ice phase transition is a common phenomenon in nature, which has never failed to remain an important topic in many research fields. For example, a significant issue is how to avoid the formation of ice crystals in the cryopreservation of biological tissues [1-6]. Since biological tissues contain a lot of water, ice crystals formed during the freezing process damage tissues and cells, directly through mechanical crushing or indirectly through solution effects [7-10]. At present, common methods to eliminate ice crystallization include rapid cooling, adding high concentrations of low-temperature protective agents [7,10-15], etc. However, these methods have disadvantages, such as being impossible for large samples or the difficulty in removing the protective agents in subsequent steps $[16,17]$. Recently, the latest research has revealed that ice crystallization is affected by external fields, such as microwave, ultrasonic, magnetic, and electric fields [18-24].

In this paper, an innovative experimental and analytical method, combining differential scanning calorimeter (DSC) measurement with an applied electric field was realized by implanting microelectrodes in a sample crucible. The effect of alternative current (AC) electric field on ice crystallization in $\mathrm{NaCl}$ aqueous solution was studied with quantitative calculation. The results show that the crystallization ratio of ice crystals is significantly reduced under external AC electric field, varies with frequency, and is related to the relaxation polarization of hydrated ions. This may provide a potential physical approach and theoretical basis for cryopreservation technology.

\section{Materials and Methods}

A $0.9 \mathrm{wt} \% \mathrm{NaCl}$ aqueous solution, which is also called normal saline, was used as the sample. The corresponding molality was $1.552 \times 10^{-4} \mathrm{~mol} / \mathrm{g}$, and the osmotic pressure was basically equal to that of mammalian blood plasma. Deionized water was also used as a reference. 
In order to ensure that the electric field was applied simultaneously during the DSC (TA Instruments, New Castle, DE, USA) cooling processes, a bespoke crucible was specially designed, as shown in Figure 1. A pair of microelectrodes were placed in a ceramic crucible perpendicularly to the crucible bottom. Two small notches were drilled at the edge of the crucible cover to ensure that the cover could still be placed flat, with enameled wires extending from the crucible. The measured samples were placed in the gap between the microelectrodes. The width of the gap was $350 \mu \mathrm{m}$. Microelectrodes were connected to a voltage source providing adjustable sinusoidal $\mathrm{AC}$ voltage $\left(V_{\mathrm{pp}}=20 \mathrm{~V}, E=57 \mathrm{kV} / \mathrm{m}\right.$, $f=0 \sim 10 \mathrm{MHz}$ ). The physical and chemical properties of this crucible with microelectrodes remained stable in the whole experimental temperature range and did not affect the performance of other related instruments and the subsequent test results.

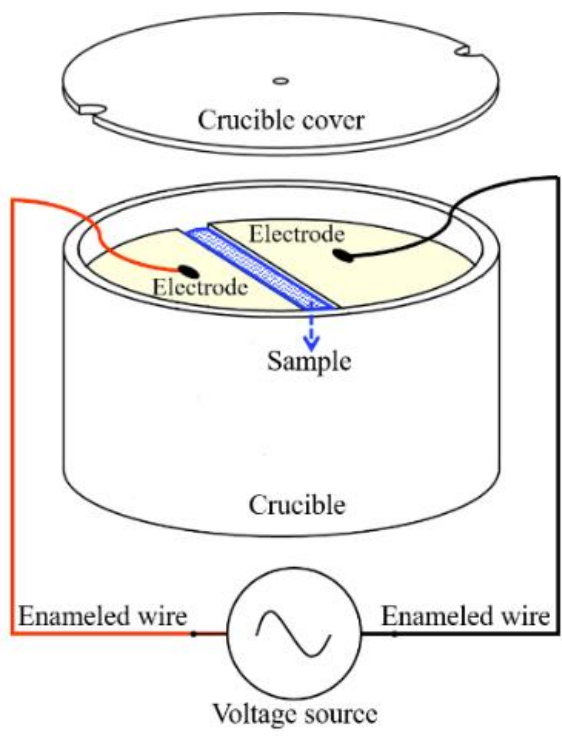

Figure 1. DSC sample crucible with microelectrodes.

The DSC procedure is illustrated in Figure 2. For the experimental group, i.e., the field cooling group, the procedure was as follows: maintained at $4{ }^{\circ} \mathrm{C}$ for $2 \mathrm{~min}$, cooling to $-60{ }^{\circ} \mathrm{C}$ at $3{ }^{\circ} \mathrm{C} / \mathrm{min}$ with applied $\mathrm{AC}$ electric field $E$, constant temperature at $-60{ }^{\circ} \mathrm{C}$ for $5 \mathrm{~min}$, turning off the voltage source, and rising to $10^{\circ} \mathrm{C}$ at $3^{\circ} \mathrm{C} / \mathrm{min}$. The procedure of the control group, i.e., the non-field cooling group, was the same, except that $E=0 \mathrm{kV} / \mathrm{m}$ during cooling. Deionized water was also tested as a reference in this group. All measurements were repeated three times. In order to compare the results more intuitively and avoid the impact of different sample sizes, $4 \mu \mathrm{L}$ solution was taken for each test using a micropipette. Rewarming DSC curves were selected for quantitative analysis, since supercooling while freezing brings great interference to the quantitative calculation of cooling DSC curves, and differences in crystallization among samples can be directly reflected through rewarming DSC curves.

The dielectric spectra of $0.9 \mathrm{wt} \% \mathrm{NaCl}$ solution were also investigated. The complex dielectric constant $\varepsilon^{*}$ was measured, and the dielectric loss tangent $\tan \delta$ was calculated $[25,26]$ in the range of $1 \mathrm{~Hz}-10 \mathrm{MHz}$ from $4{ }^{\circ} \mathrm{C}$ to $-6^{\circ} \mathrm{C}$.

$$
\begin{gathered}
\varepsilon^{*}=\varepsilon^{\prime}-j \varepsilon^{\prime \prime} \\
\tan \delta=\varepsilon^{\prime \prime} / \varepsilon^{\prime}
\end{gathered}
$$

$\varepsilon^{\prime}$ is the relative dielectric constant, $\varepsilon^{\prime \prime}$ is the dielectric loss factor, and $\delta$ is the dielectric loss angle. $\tan \delta$ refers to the energy consumed by the dielectric in converting electric energy into heat energy per unit volume per unit time, and is an attribute of the dielectric itself. In many cases, $\tan \delta$ is much more sensitive to the change of medium characteristics. 


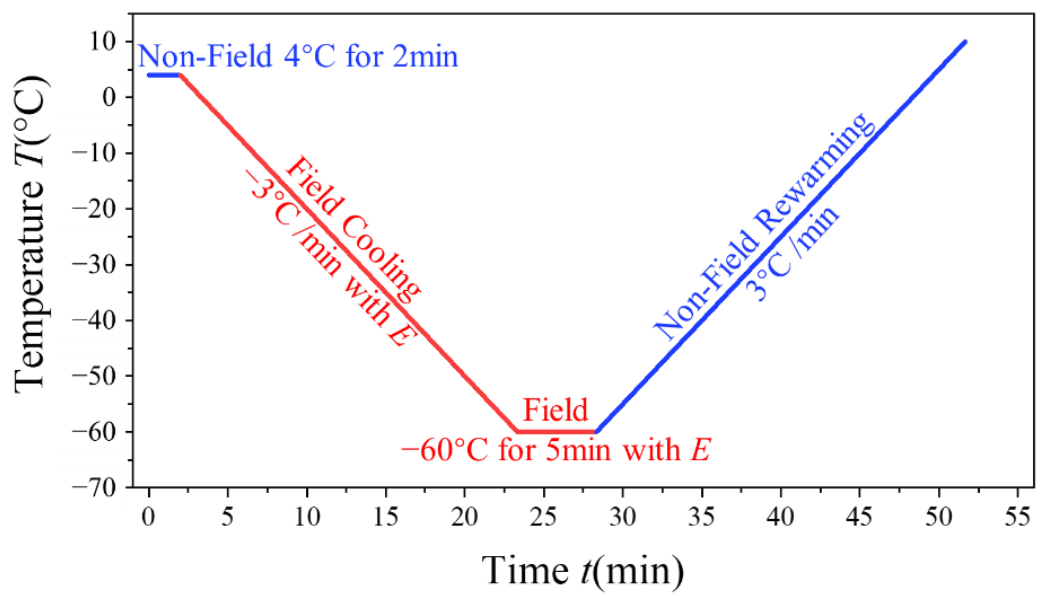

Figure 2. Temperature-time procedure for DSC measurement.

A broadband dielectric spectrometer (Novocontrol Technologies, Montabaur, Germany) was used for dielectric measurement. The measurement accuracy of $\tan \delta$ was better than $3 \times 10^{-5}$, and the measurement resolution was less than $10^{-5}$. For each measured frequency, the output result of the spectrometer was an average value obtained by multiple automatic measurements.

A liquid parallel plate sample cell BDS1308 with two parallel electrodes inside was used, which was sealed to prevent liquid evaporation. The diameter of electrodes was $20 \mathrm{~mm}$. The gap between electrodes was $0.1 \mathrm{~mm}$, adjusted by two silicon dioxide spacers placed in parallel. The stray capacitance of the sample cell was taken into account by open-circuit calibration before measurements. The root-mean-square value of the AC voltage applied to the electrodes was $V_{\text {rms }}=1 \mathrm{~V}$.

The sample and the sample cell were pre-cooled to $4{ }^{\circ} \mathrm{C}$ for $10 \mathrm{~min}$ before the start of measurements, to exclude the influence of thermal history on the measurement results. From $4{ }^{\circ} \mathrm{C}$ to $-6{ }^{\circ} \mathrm{C}$, the dielectric spectrum was measured every $2{ }^{\circ} \mathrm{C}$. The temperature remained constant during the measurement. Each measurement took about $5 \mathrm{~min}$. The temperature control accuracy was $\pm 0.5^{\circ} \mathrm{C}$.

\section{Results}

\subsection{Variation of DSC Rewarming Curves under AC Electric Field}

Figure 3 shows the rewarming DSC curves of the $\mathrm{NaCl}$ solution and deionized water. The sole melting peak of deionized water is caused by pure ice (PI) which is crystals formed by the ordered arrangement of water molecules, and so is the higher temperature melting peak of $\mathrm{NaCl}$ solution. The lower temperature melting peak is a eutectic melting peak related to the ions, and is caused by the salty ice (SI), which is a mixture of fine ice crystals and $\mathrm{NaCl} \cdot 2 \mathrm{H}_{2} \mathrm{O}[27,28]$. During freezing, pure ice crystals first grow around the ice nuclei formed by water clusters. The leftover liquid water molecules and ions near crystal boundaries then tend to form a high-concentration solution, and finally transform into salty ice. Salty ice melts first, and pure ice later, during rewarming.

Compared with non-field cooling, the positions of the salty ice peaks and pure ice peaks remain steady after field cooling, which indicates that the physical properties of pure water ice and salty ice do not change under an electric field, since the melting point is one of the symbolic physical properties of a material.

The area of each peak equals the melting heat $\Delta Q$ and can be obtained by integration $[29,30]$ :

$$
\Delta Q=\frac{1}{\beta} \int_{T_{1}}^{T_{2}} \Phi d T
$$

where $\Phi$ is the heat flow, $\beta$ is the heating rate, and $T_{1}$ and $T_{2}$ are the starting and ending temperature of the peak. 


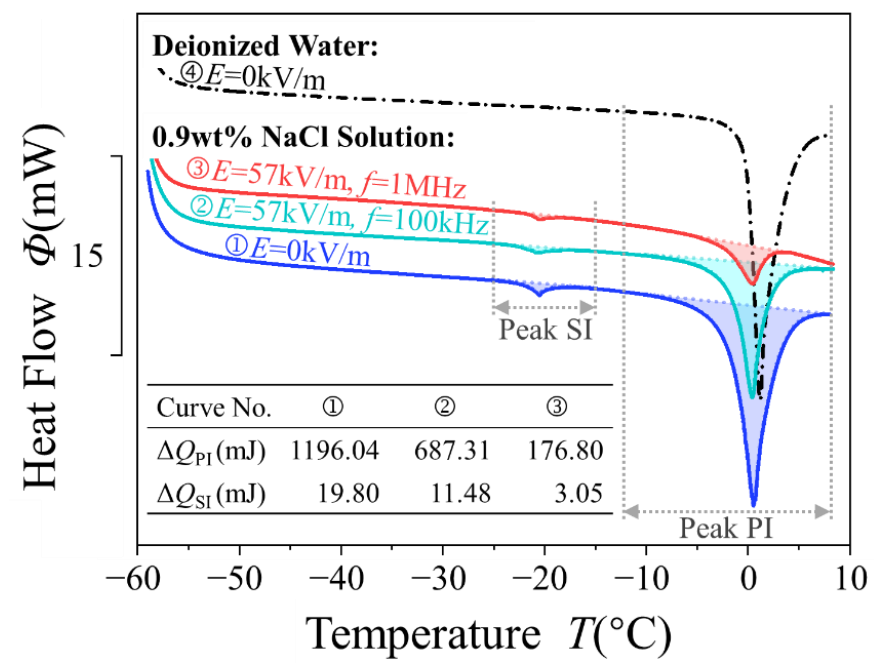

Figure 3. DSC rewarming curves of 0.9 wt $\% \mathrm{NaCl}$ solution after non-field cooling and field cooling.

The integration results are given in Figure 3. The $\Delta Q$ after field cooling decreased significantly, indicating that the amounts of pure ice and salty ice involved in the melting process were less than after non-field cooling. That is, the external AC electric field hindered the crystallization during the freezing process and provides a promising method to reduce the formation of ice crystals. The possibility remains that the change of $\Delta Q$ was due to water transforming into ice with another crystal structure, but previous studies have shown that the electric field mainly affects the water-ice transition through changing the nucleation process, as well as the crystal growth, rather than through variation of ice structure [31,32].

\subsection{Variation of Crystallization Ratio with Electric Field Frequency}

In order to analyze quantitatively, with normalization, the crystallization ratio of pure ice $\eta_{\text {PI }}$ and all ice crystals $\eta_{\text {all }}$ with field cooling and non-field cooling were defined and calculated based on melting heat $\Delta Q$.

$$
\begin{gathered}
\eta_{\mathrm{PI}}=\frac{\Delta Q_{\mathrm{PI}}}{\Delta Q_{\mathrm{PI}}^{0}}, \\
\eta_{\text {all }}=\frac{\Delta Q_{\mathrm{PI}}+\Delta Q_{\mathrm{SI}}}{\Delta Q_{\mathrm{PI}}^{0}+\Delta Q_{\mathrm{SI}}^{0}}
\end{gathered}
$$

$\Delta Q_{\mathrm{PI}}$ and $\Delta Q_{\mathrm{SI}}$ correspond to melting heats after field cooling, while $\Delta Q_{\mathrm{PI}}^{0}$ and $\Delta Q_{\mathrm{SI}}^{0}$ are after non-field cooling. The smaller the $\eta_{P I}$ and $\eta_{\text {all }}$, the more effective the corresponding applied electric field.

The calculation results are shown in Figure 4. It can be seen that the application of an AC electric field decreases $\eta_{\mathrm{PI}}$ and $\eta_{\text {all }}$. The minimum $\eta_{\mathrm{PI}}$ and $\eta_{\text {all }}$ both exist at the optimum frequency $f=1 \mathrm{MHz}$. In addition, the changing trend of $\eta_{\mathrm{PI}}$ and $\eta_{\text {all }}$ is common to both, and the difference between them is unclear. Thus, the effect of an AC electric field on solution freezing is mainly reflected in the inhibition of the growth of pure ice crystals. 


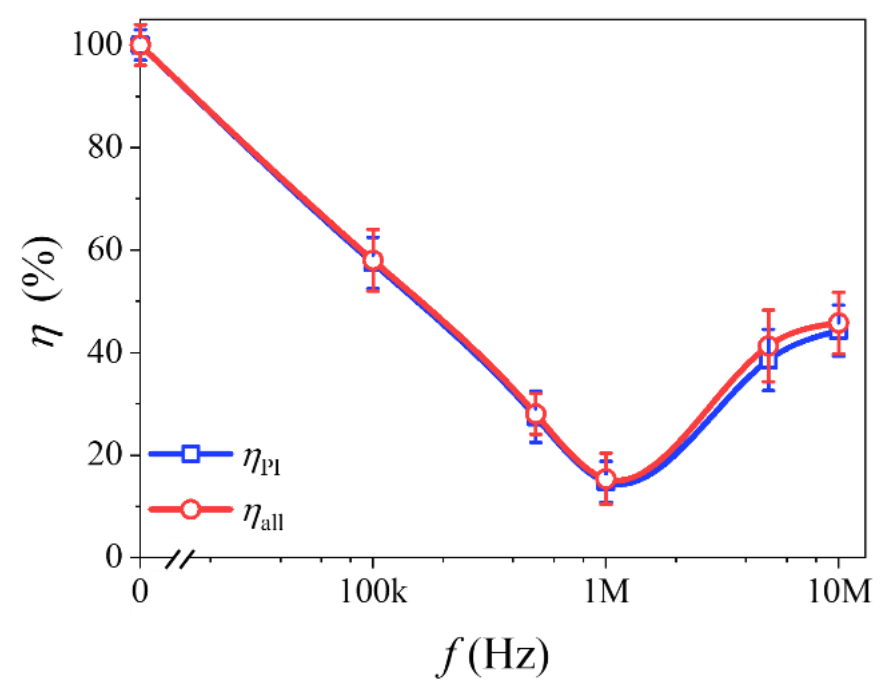

Figure 4. The crystallization ratio of pure ice $\eta_{\mathrm{PI}}$ and all ice crystals $\eta_{\text {all }}$.

\subsection{Dielectric Spectrum of $\mathrm{NaCl}$ Aqueous Solution during Cooling}

To further explore the mechanism of the strong dependence of $\eta_{\mathrm{PI}}$ and $\eta_{\mathrm{all}}$ on frequency, the dielectric spectra of a $0.9 \mathrm{wt} \% \mathrm{NaCl}$ aqueous solution during cooling were measured. Since the electric field was applied during freezing for DSC measurement, it is important to pay attention to the dielectric spectrum near the liquid-solid phase transition temperature during cooling, which can be very helpful for discovering the mechanism of the effect of an electric field on crystallization inhibition. Figure 5 shows the dielectric temperature spectra of $0.9 \mathrm{wt} \% \mathrm{NaCl}$ aqueous solution from $4{ }^{\circ} \mathrm{C}$ to $-6^{\circ} \mathrm{C}$, close to its liquid-solid transition temperature range of -5.9 to $-7.4^{\circ} \mathrm{C}[33]$.

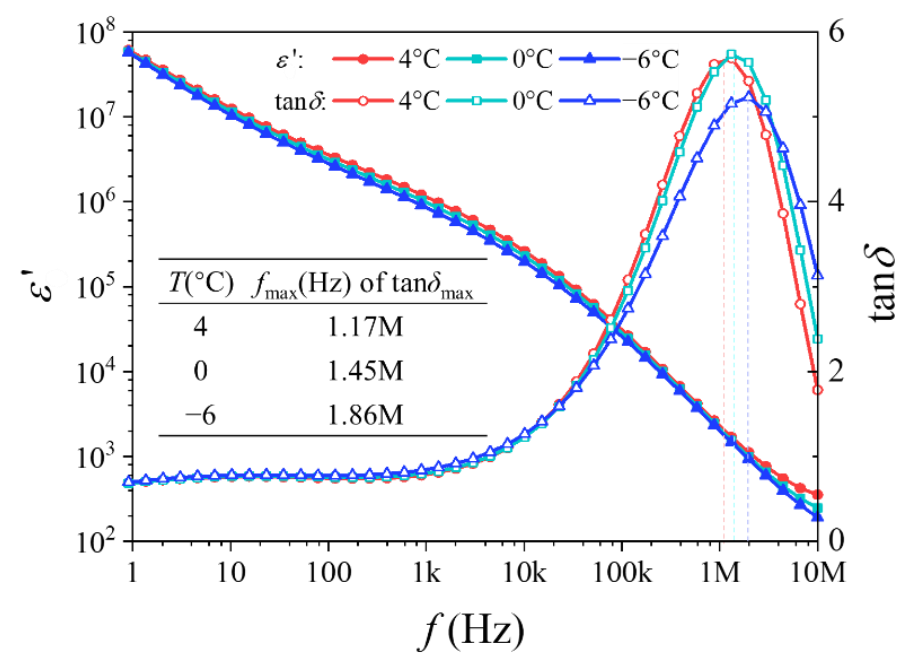

Figure 5. Dielectric spectrum during cooling from $4{ }^{\circ} \mathrm{C}$ to $-6{ }^{\circ} \mathrm{C}$.

The relative dielectric constant $\varepsilon^{\prime}$ decreases very quickly with the increase of frequency, which suggests a relaxation process of hydrated ions. Previous investigations have shown that such a process can be interpreted using the Mangelsdorf and White model [34] from the point view of dielectrophoresis (DEP). The rise of $\varepsilon^{\prime}$ at low frequency can be ascribed to the effect of electrodes [35]. However, the electrode polarization occurs below $1 \mathrm{kHz}$, which does not interfere with the observation and analysis of the concerned relaxation polarization of hydrated ions.

The dielectric loss tangent $\tan \delta$ has an obvious peak near $f_{\max }=1 \mathrm{MHz}$, consistent with the optimum frequency of the DSC study above. This reveals that the effect of an 
external AC electric field on the freezing process is related to some kind of relaxation polarization. Since the orientation polarization of water molecules and the induced polarization of hydrated ions appear in the range of $0.1-20 \mathrm{GHz}[36,37]$ and $10 \mathrm{kHz}-10 \mathrm{MHz}$ [34], respectively, and the relative dielectric constant $\varepsilon^{\prime}$ decreases more rapidly above $10 \mathrm{kHz}$, the relaxation polarization effect is not caused by the water molecules, but hydrated ions.

Thus, it is inferred that the relaxation polarization of hydrated ions is the main reason for the inhibition of ice crystallization in a solution when freezing under an AC electric field.

\section{Discussion}

To complete the transition from liquid phase to solid phase and integrate into the lattice structure of ice, water molecules need to overcome the constraints of kinetic energy and potential energy generated by thermal motion and overcome the solid-liquid interface energy.

In $\mathrm{NaCl}$ solution, $\mathrm{Na}^{+}$and $\mathrm{Cl}^{-}$ions are hydrated to form bilayer hydrated ions with opposite charge signs, as shown in Figure 6. The inner layer is strongly bound, and the outer layer is weakly bound. Under an external electric field, the central ion and the strongly bound layer move towards the field direction, and the positive and negative centers of hydrated ions no longer coincide, resulting in induced dipole moments.

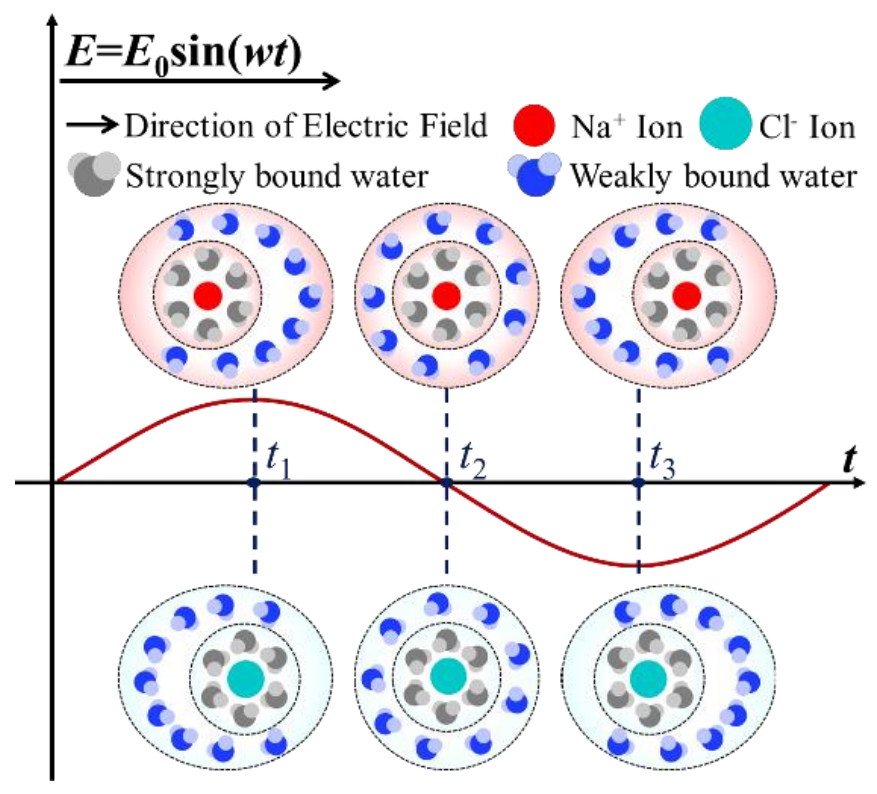

Figure 6. Induced dipoles of hydrated ions under an AC electric field.

Under the application of an AC electric field, the polarization relaxation of hydrated ions destroys the original charge balance, interferes with the original molecular arrangement structure in the solution, and increases the kinetic energy of water molecules because of the friction between the weakly bound water and the water molecules surrounding the hydrated ions; thus, inhibiting the crystal growth of ice.

When the electric field frequency is low enough, the polarization of hydrated ions can keep up with the change of frequency, and the change in direction of the induced dipole is slow. The relatively small disturbance of the solution has a slight influence on the formation and growth process of ice crystals. With an increase of frequency, the polarization gradually lags behind the electric field, resulting in relaxation polarization, the disturbance of the molecular distribution in solution increases, and this has a significant impact on the growth process of ice crystals. With a further increase of frequency, the polarization of hydrated ions cannot keep up with the change of the electric field and can only make small vibrations at the original position; the disturbance is weakened, and the influence on crystallization is also weakened. 
Therefore, the influence of hydrated ions on the solution phase transition process under an AC electric field is related to frequency and is the most significant near the range of dielectric relaxation. In addition, this corresponding dielectric relaxation is consistent with the theoretical calculations of the frequency range of induced polarization for hydrated ions in previous works [34,38], which also provide convincing evidence that the ice crystallization inhibition is contributed to by the dielectric relaxation of hydrated ions.

\section{Conclusions}

An innovative crucible with microelectrodes was designed, which enabled a synchronous application of an external electric field during DSC measurements. According to quantitative calculations based on DSC rewarming curves, it was found that ice crystallization in $0.9 \mathrm{wt} \% \mathrm{NaCl}$ aqueous solution can be effectively inhibited by AC electric field cooling in the range of $100 \mathrm{kHz}$ to $10 \mathrm{MHz}$. Compared with non-field cooling, the crystallization ratio of pure ice $\eta_{\mathrm{PI}}$ and all ice crystals $\eta_{\text {all }}$ decreases at first, and then increases, with the increase of frequency, when field cooling with an external AC electric field. A window effect appears near $f=1 \mathrm{MHz}$, where $\eta_{\mathrm{PI}}$ and $\eta_{\text {all }}$ are reduced to less than $20 \%$. This frequency is related to the frequency corresponding to the polarization relaxation process of hydrated ions near the liquid-solid transition temperature of the solution. This study may provide a theoretical basis for ice crystal inhibition while freezing and has application potential for the cryopreservation of biomaterials.

\section{Patents} follows:

Two patents resulting from the work are in the application process and are listed as

1. DSC Thermal Analysis Method for Action of Applied Electric Field, Publication No.US-2021-0041381-A1;

2. DSC Electrode System Capable of Applying Electric Field, Publication No.US-20210037812-A1.

Author Contributions: Conceptualization, L.Z.; methodology, X.S., L.Z. and J.G.; software, X.S.; validation, X.S. and J.G.; formal analysis, X.S.; investigation, X.S.; resources, L.Z. and J.G.; data curation, X.S.; writing—original draft preparation, X.S.; writing—review and editing, X.S., L.Z. and J.G.; visualization, X.S.; supervision L.Z. and J.G.; project administration, L.Z.; funding acquisition, L.Z. All authors have read and agreed to the published version of the manuscript.

Funding: This work was funded by National Basic Research Program of China, grant number 2011 CB503701.

Institutional Review Board Statement: Not applicable.

Informed Consent Statement: Not applicable.

Data Availability Statement: The data presented in this study are available on request from the corresponding author. The data are not publicly available due to fund requirements.

Conflicts of Interest: The authors declare no conflict of interest.

\section{References}

1. Bagchi, A.; Woods, E.J.; Critser, J.K. Cryopreservation and vitrification: Recent advances in fertility preservation technologies. Expert Rev. Med. Devic. 2008, 5, 359-370. [CrossRef]

2. Farrant, J. Mechanism of Cell Damage during Freezing and Thawing and Its Prevention. Nature 1965, 205, 1284. [CrossRef]

3. Karlsson, J.O.M.; Cravalho, E.G.; Toner, M. A Model of Diffusion-Limited Ice Growth inside Biological Cells during Freezing. J. Appl. Phys. 1994, 75, 4442-4445. [CrossRef]

4. Mazur, P. Cryobiology: The Freezing of Biological Systems. Science 1970, 168, 939-949. [CrossRef]

5. Zhao, Y.H.; Powell-Palm, M.J.; Ukpai, G.; Bilbao-Sainz, C.; Chen, L.B.; Wang, J.J.; Rubinsky, B. Phase change interface stability during isochoric solidification of an aqueous solution. Appl. Phys. Lett. 2020, 117, 133701:1-133701:6. [CrossRef]

6. Zhmakin, A.I. Physical aspects of cryobiology. Phys. Usp. 2008, 51, 231-252. [CrossRef] 
7. Karlsson, J.O.M.; Toner, M. Chapter 24-Cryopreservation. In Principles of Tissue Engineering, 2nd ed.; Lanza, R.P., Langer, R., Vacanti, J., Eds.; Academic Press: San Diego, CA, USA, 2000; pp. 293-307. [CrossRef]

8. Prickett, R.C.; Marquez-Curtis, L.A.; Elliott, J.A.W.; McGann, L.E. Effect of supercooling and cell volume on intracellular ice formation. Cryobiology 2015, 70, 156-163. [CrossRef]

9. Yang, G.; Zhang, A.L.; Xu, L.X.; He, X.M. Modeling the cell-type dependence of diffusion-limited intracellular ice nucleation and growth during both vitrification and slow freezing. J. Appl. Phys. 2009, 105, 114701:1-114701:11. [CrossRef]

10. Zhao, G.; Takamatsu, H.; He, X.M. The effect of solution nonideality on modeling transmembrane water transport and diffusionlimited intracellular ice formation during cryopreservation. J. Appl. Phys. 2014, 115, 144701:1-144701:13. [CrossRef]

11. Devismita, D.; Kumar, A. Effect of cryoprotectant on optimal cooling rate during cryopreservation. Cryobiology 2015, 70, 53-59. [CrossRef]

12. He, X.M.; Fowler, A.; Toner, M. Water activity and mobility in solutions of glycerol and small molecular weight sugars: Implication for cryo- and lyopreservation. J. Appl. Phys. 2006, 100, 074702:1-074702:11. [CrossRef]

13. Kuleshova, L.L.; Lopata, A. Vitrification can be more favorable than slow cooling. Fertil. Steril. 2002, 78, 449-454. [CrossRef]

14. Su, F.M.; Fan, Y.M.; Xu, H.; Zhao, N.N.; Ji, Y.L.; Deng, Y.B.; Ma, H.B. Thin-Film Evaporation Heat Transfer of Liquid Nitrogen and Its Application in Cell Vitrification. J. Heat Transfer 2020, 142, 071602:1-071602:6. [CrossRef]

15. Su, F.M.; Ma, H.B.; Han, X.; Chen, H.H.; Tian, B.H. Ultra-high cooling rate utilizing thin film evaporation. Appl. Phys. Lett. 2012, 101, 113702:1-113702:3. [CrossRef] [PubMed]

16. Karlsson, J.O.M.; Toner, M. Long-term storage of tissues by cryopreservation: Critical issues. Biomaterials 1996, 17, $243-256$. [CrossRef]

17. Kilbride, P.; Lamb, S.; Milne, S.; Gibbons, S.; Erro, E.; Bundy, J.; Selden, C.; Fuller, B.; Morris, J. Spatial considerations during cryopreservation of a large volume sample. Cryobiology 2016, 73, 47-54. [CrossRef]

18. Dalvi-Isfahan, M.; Hamdami, N.; Xanthakis, E.; Le-Bail, A. Review on the control of ice nucleation by ultrasound waves, electric and magnetic fields. J. Food Eng. 2017, 195, 222-234. [CrossRef]

19. James, C.; Purnell, G.; James, S.J. A Review of Novel and Innovative Food Freezing Technologies. Food Bioprocess. Tech. 2015, 8, 1616-1634. [CrossRef]

20. Jha, P.K.; Xanthakis, E.; Jury, V.; Havet, M.; Le-Bail, A. Advances of electro-freezing in food processing. Curr. Opin. Food Sci. 2018, 23, 85-89. [CrossRef]

21. Kumar, P.K.; Rasco, B.A.; Tang, J.; Sablani, S.S. State/Phase Transitions, Ice Recrystallization, and Quality Changes in Frozen Foods Subjected to Temperature Fluctuations. Food Eng. Rev. 2020, 12, 421-451. [CrossRef]

22. Ma, Y.H.; Zhong, L.S.; Gao, J.H.; Liu, L.; Hu, H.Y.; Yu, Q.X. Manipulating ice crystallization of 0.9 wt.\% NaCl aqueous solution by alternating current electric field. Appl. Phys. Lett. 2013, 102, 183701:1-183701:4. [CrossRef]

23. Okuda, K.; Kawauchi, A.; Yomogida, K. Quality improvements to mackerel (Scomber japonicus) muscle tissue frozen using a rapid freezer with the weak oscillating magnetic fields. Cryobiology 2020, 95, 130-137. [CrossRef]

24. Otero, L.; Rodriguez, A.C.; Perez-Mateos, M.; Sanz, P.D. Effects of Magnetic Fields on Freezing: Application to Biological Products. Compr. Rev. Food Sci. F 2016, 15, 646-667. [CrossRef] [PubMed]

25. Ali, A.; Jameel, M.H.; Uddin, S.; Zaman, A.; Iqbal, Z.; Gul, Q.; Sultana, F.; Mushtaq, M.; Althubeiti, K.; Ullah, R. The Effect of Ca Dopant on the Electrical and Dielectric Properties of $\mathrm{BaTi}_{4} \mathrm{O}_{9}$ Sintered Ceramics. Materials 2021, 14, 5375. [CrossRef] [PubMed]

26. Shcherbakov, V.V.; Artemkina, Y.M.; Akimova, I.A.; Artemkina, I.M. Dielectric Characteristics, Electrical Conductivity and Solvation of Ions in Electrolyte Solutions. Materials 2021, 14, 5617. [CrossRef] [PubMed]

27. Song, X.; Zhong, L.; He, J.; Qiu, M.; Gao, J.; Yu, Q. Cryogenic Characteristics and Relaxation Polarization Mechanism of NaCl Aqueous Solutions. In Proceedings of the 2019 IEEE Conference on Electrical Insulation and Dielectric Phenomena (CEIDP), Richland, WA, USA, 20-23 October 2019; pp. 721-724. [CrossRef]

28. Chen, N.; Morikawa, J.; Hashimoto, T. Effect of cryoprotectants on eutectics of $\mathrm{NaCl} \cdot 2 \mathrm{H}_{2} \mathrm{O} /$ ice and $\mathrm{KCl} /$ ice studied by temperature wave analysis and differential scanning calorimetry. Thermochim. Acta 2005, 431, 106-112. [CrossRef]

29. Faroongsarng, D. Theoretical Aspects of Differential Scanning Calorimetry as a Tool for the Studies of Equilibrium Thermodynamics in Pharmaceutical Solid Phase Transitions. AAPS PharmSciTech 2016, 17, 572-577. [CrossRef]

30. Höhne, G.W.H.; Hemminger, W.F.; Flammersheim, H.-J. DSC Curves and Further Evaluations. In Differential Scanning Calorimetry; Springer: Berlin/Heidelberg, Germany, 2003; pp. 115-146. [CrossRef]

31. Petersen, A.; Rau, G.; Glasmacher, B. Reduction of primary freeze-drying time by electric field induced ice nucleus formation. Heat Mass Transfer. 2006, 42, 929-938. [CrossRef]

32. Braslavsky, I.; Lipson, S.G. Electrofreezing effect and nucleation of ice crystals in free growth experiments. Appl. Phys. Lett. 1998, 72, 264-266. [CrossRef]

33. Ma, Y.; Zhong, L.; Zhang, H.; Xu, C. Effect of applied electric field on the formation and structure of ice in biomaterials during freezing. In Proceedings of the 2010 10th IEEE International Conference on Solid Dielectrics (ICSD), Potsdam, Germany, 4-9 July 2010; pp. 1-4. [CrossRef]

34. Zhou, H.; Preston, M.A.; Tilton, R.D.; White, L.R. Calculation of the electric polarizability of a charged spherical dielectric particle by the theory of colloidal electrokinetics. J. Colloid Interf. Sci. 2005, 285, 845-856. [CrossRef] [PubMed]

35. Iwamoto, M. Maxwell-Wagner Effect. In Encyclopedia of Nanotechnology; Bhushan, B., Ed.; Springer: Dordrecht, The Netherlands, 2014; pp. 1-13. [CrossRef] 
36. Kaatze, U. Complex permittivity of water as a function of frequency and temperature. J. Chem. Eng. Data 1989, 34, 371-374. [CrossRef]

37. Peyman, A.; Gabriel, C.; Grant, E.H. Complex permittivity of sodium chloride solutions at microwave frequencies. Bioelectromagnetics 2007, 28, 264-274. [CrossRef] [PubMed]

38. Hinch, E.J.; Sherwood, J.D.; Chew, W.C.; Sen, P.N. Dielectric Response of a Dilute Suspension of Spheres with Thin Double-Layers in an Asymmetric Electrolyte. J. Chem. Soc. Faraday Trans. 2 1984, 80, 535-551. [CrossRef] 